\title{
Evidence of Borrelia in wild and domestic mammals from the state of Minas Gerais, Brazil
}

\author{
Evidência de Borrelia em mamíferos silvestres e domésticos no Estado de Minas Gerais, Brasil \\ Carlos Emmanuel Montandon ${ }^{1}$; Natalino Hajime Yoshinari²; Bruno Silva Milagres ${ }^{1,3}$; Rafael Mazioli ${ }^{1}$; \\ Gabriel Guimarães Gomes ${ }^{1}$; Higo Nasser Moreira ${ }^{1}$; Amanda de Freitas Padilha ${ }^{4}$; Guido Gomes Wanderley 5 \\ Elenice Mantovani²; Márcio Antônio Moreira Galvão ${ }^{4}$; Helio Langoni; Cláudio Mafra ${ }^{1 *}$
}

\begin{abstract}
${ }^{1}$ Departamento de Bioquímica e Biologia Molecular, Universidade Federal de Viçosa - UFV, Viçosa, MG, Brazil
${ }^{2}$ Faculdade de Medicina, Universidade de São Paulo - USP, São Paulo, SP, Brazil

${ }^{3}$ Programa de Treinamento em Epidemiologia Aplicado à Saúde Pública, Ministério da Saúde, Brasília, DF, Brazil

${ }^{4}$ Departamento de Ciências Médicas, Universidade Federal de Ouro Preto - UFOP, Ouro Preto, MG, Brazil

${ }^{5}$ Faculdade de Medicina Veterinária e Zootecnia, Universidade de São Paulo - USP, São Paulo, SP, Brazil
\end{abstract}

Received December 18, 2013

Accepted May 21, 2014

\begin{abstract}
The main of the study was to evaluate the presence of Borrelia burgdorferi infection in domestic and wild vertebrates and ectoparasites in endemic areas from the state of Minas Gerais, Brazil. A total of 445 serum samples were examined by ELISA, which used the Borrelia burgdorferi strain G39/40 U.S. source and 3,821 tick samples were tested by polymerase chain reaction (PCR). B. burgdorferi antibodies were found in 30 serum samples (6.74\%); three in marsupials $(7.69 \%)$, three in rodents $(2.80 \%)$, nine in dogs $(6.25 \%)$, and 15 in horses $(9.68 \%)$. Nested-PCR performed in DNA samples obtained from collected ticks demonstrated negative results. Although attempts to amplify B. burgdorferi DNA from ticks had been not successful, the presence of seroreactive vertebrates suggests the possibility the Borrelia species circulating in these regions. Further research is required to provide information on the presence of Borrelia in Brazilian territory and its association with Baggio-Yoshinari syndrome.
\end{abstract}

Keywords: Lyme-disease, Baggio-Yoshinari Syndrome, tick-borne diseases, borreliosis.

\section{Resumo}

O principal objetivo do estudo foi avaliar a presença de infecção por Borrelia burgdorferi em vertebrados domésticos e silvestres e ectoparasitas em áreas endêmicas do estado de Minas Gerais, Brasil. Um total de 445 amostras de soro foram examinadas por ELISA, onde usou-se a cepa americana G39/40 de Borrelia burgdorferi e 3.821 amostras de carrapatos foram testados pela reação em cadeia da polimerase (PCR). Anticorpos anti -B. burgdorferi foram encontrados em 30 amostras de soro $(6,74 \%)$; três marsupiais $(7,69 \%)$, três em roedores $(2,80 \%)$, em nove cáes $(6,25 \%)$ e 15 em cavalos (9,68\%). Nested-PCR realizada em amostras de DNA obtidas a partir de carrapatos coletados demonstraram resultados negativos. Apesar das tentativas para amplificar o DNA de B. burgdorferi a partir de carrapatos náo tenha sido bem sucedido, a presença de soroatividade em vertebrados sugere a possibilidade de espécies de Borrelia circulando nestas regióes. Mais pesquisas são necessárias para fornecer informaçôes sobre a presença de Borrelia em território brasileiro e sua associação com a Síndrome de Baggio-Yoshinari.

Palavras-chave: Doença de Lyme, Síndrome Baggio-Yoshinari, doenças transmitidas por carrapatos, borreliose.

\footnotetext{
${ }^{*}$ Corresponding author: Cláudio Mafra

Departamento de Bioquímica e Biologia Molecular, Universidade Federal de

Viçosa - UFV, CEP 36570-900, Viçosa, MG, Brazil

e-mail: mafra@ufv.br

Financial support: This project was supported by the Foundation for Research of the State of Minas Gerais (FAPEMIG) (Process \# APQ-01453-10). B. S. Milagres was granted a Postdoctoral Fellowship by FAPEMIG (Process \# BPD00019-10)
} 
Microorganisms of genus Borrelia are Gram-negative multi-flagellated bacteria, belonging to family Spirochetaceae (KRUPKA et al., 2007). Lyme disease (LD) is considered the most important emerging zoonosis in the United States of America and Europe (KRUPKA et al., 2007), causing skin, joint, neurological, cardiac and ocular symptoms. LD is caused by Borrelia burgdorferi sensu lato bacterium complex, which comprises a group of 12 distinct species; it is transmitted by ticks of Ixodes ricinus complex (JOPPERT, 1995; RANKA et al., 2004).

In Brazil, a similar disease, referred as Brazilian Lyme diseasesimile illness or Baggio-Yoshinari Syndrome (BYS) has been described, since last ending century (YOSHINARI et al., 2010; GOUVEIA et al., 2010). Mantovani et al. (2007) were unable to confirm whether this syndrome is caused by new Borrelia species or it is related to genetically modified Borrelia burgdorferi sensu lato microorganisms or other infectious agent.

Give that BYS is considered a zoonosis as LD, it is very important to verify the presence of the causing agents in wild and domestic animals and theirs ectoparasites. In this scenario, the goal of this research was to investigate the occurrence of antibodies against $B$. burgdorferi in domestic and wild animals and the presence of Borrelia DNA in ticks.

This study was realized in the municipalities of Santa Cruz do Escalvado (20¹4'09" S 42\%48'50" W), Pingo D'Água (1943'37”

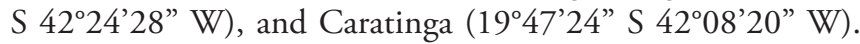
These municipalities are located in the Rio Doce Hydrographic Basin in the State of Minas Gerais, Brazil, being classified as endemic areas for tick-borne zoonosis, and characterized by intense anthropogenic destructive actions against the ecological system. In the municipalities of Santa Cruz do Escalvado and Pingo D’Água, blood samples from 445 animals were collected from the tail vein of rodents and marsupials, cephalic vein of dogs, and jugular vein of horses, as previously approved by Brazilian Institute of Environment and Natural Renewable Resources (IBAMA) and the Ethics Committee of the Federal University of Vicosa. These samples were stored at $-20{ }^{\circ} \mathrm{C}$ until the time of use. After blood collection, the wild animals captured were morphologically identified (ROSSI et al., 2006; OLIVEIRA; BONVICINO, 2006) and returned to their natural habitat.

A total number of 3,821 ticks were collected from wild and domestic animals in the parasitic stage and from the ground in the municipalities of Santa Cruz do Escalvado, Pingo D’Água, and Caratinga. The ticks were taxonomically identified by external morphological characteristics according to Aragão and Fonseca (1961) and Linardi and Guimarães (2000); they were sorted into pools according to each mammalian parasitized, been maintained at $37^{\circ} \mathrm{C}$ under biochemical oxygen demand (BOD) conditions for 48 hours. After that, the ectoparasites were separated in pools according to taxonomic identification and animal origin, followed by storage at $-20^{\circ} \mathrm{C}$ until DNA extraction.

Of 445 animals, 332 were from the municipality of Santa Cruz Escalvado - 38 Didelphis aurita, 64 rodents, 119 dogs and 11 horses -, and 113 were of Pingo D'Água - one Didelphis aurita, 43 rodents, 25 dogs, and 44 horses. The rodents were identified as Nectomys squamipes, Rattus rattus, Oryzomys subflavus, and Akodon sp. The serological test using immunoenzymatic assay (ELISA) as previously described (GRODZICKI; STEERE, 1988; COSTA, 1998) showed reactivity in 30 (6.74\%) serum samples of 445 animals tested; $7.89 \%$ in marsupials $(n=3), 2.80 \%$ in rodents $(n=3), 6.25 \%$ in dogs $(n=9)$, and $9.68 \%$ in horses $(\mathrm{n}=15)$ (Tables 1 and 2).

In this study we found high anti-Borrelia titers - 1:800 to 1:3,200 - among serum samples from dogs and horses in the municipality of Santa Cruz do Escalvado, where only three marsupials and two $(3.13 \%)$ rodents presented antibodies against B. burgdorferi, with titers of 1:100 and 1:400. In Pingo D'Água municipality, one $(2.33 \%)$ of 43 rodent, one $(4.00 \%)$ of $25 \mathrm{dog}$ and six (13.64\%) of 44 horse serum samples were positive with titers from 1:100 to 1:800 titers (Table 2).

To roll out possible cross reaction, but not covering all of them, serology for leptospirosis pre-exposure against 30 different serovars was performed in all serum samples using microscopic agglutination test (MAT), as previously described (POSTIC et al., 2000). In the analyzed samples, 20 (4.49\%) showed reactivity against B. burgdorferi and Leptospira spp. antigens, being 211 animals (47.42\%) Leptospira spp. reactive (Table 3).

Taxonomic identification of ectoparasites collected from marsupials, small rodents, dogs, and horses in the municipalities of Santa Cruz do Escalvado, Pingo D’Água, and Caratinga demonstrated the occurrence of the following genus/species of ticks in the studied animals species: Amblyomma cajennense $(\mathrm{n}=1,926)$, Amblyomma brasiliensis ( $\mathrm{n}=1)$, Amblyomma dubitatum $(\mathrm{n}=1)$,

Table 1. Frequencies of antibodies against Borrelia burgdorferi (ELISA - IgG) in wild and domestic animals from the municipalities of Santa Cruz do Escalvado and Pingo D’Água, Minas Gerais State, Brazil.

\begin{tabular}{|c|c|c|c|c|c|c|}
\hline & & \multicolumn{4}{|c|}{ Municipalities } & \multirow{3}{*}{$\begin{array}{l}\text { Total Positive } \\
\text { Samples (\%) }\end{array}$} \\
\hline \multirow{2}{*}{\multicolumn{2}{|c|}{ Animals }} & \multicolumn{2}{|c|}{ Santa Cruz do Escalvado } & \multicolumn{2}{|c|}{ Pingo D’Água } & \\
\hline & & $\mathbf{n}$ & $\begin{array}{c}\text { Positive Samples } \\
(\%)\end{array}$ & $\mathbf{n}$ & $\begin{array}{c}\text { Positive Samples } \\
(\%)\end{array}$ & \\
\hline \multirow[t]{3}{*}{ Wild } & Marsupials & 38 & $3(7.89)$ & 1 & $0(0.00)$ & $3(7.69)$ \\
\hline & Rodents & 64 & $2(3.13)$ & 43 & $1(2.33)$ & $3(2.80)$ \\
\hline & Subtotal & 102 & $5(4.90)$ & 44 & $1(2.27)$ & $6(4.11)$ \\
\hline \multirow[t]{4}{*}{ Domestic } & Dogs & 119 & $8(6.72)$ & 25 & $1(4.00)$ & $9(6.25)$ \\
\hline & Horses & 111 & $9(8.11)$ & 44 & $6(13.64)$ & $15(9.68)$ \\
\hline & Subtotal & 230 & $17(3.48)$ & 69 & $7(2.90)$ & $24(8.03)$ \\
\hline & Total & 332 & $22(6.63)$ & 113 & $8(7.08)$ & $30(6.74)$ \\
\hline
\end{tabular}

N.S.: n - number; \% - percentage. 
Table 2. Anti-Borrelia antibody titers in serum samples from animals captured in the municipalities of Santa Cruz do Escalvado and Pingo D’Água, state of Minas Gerais, Brazil.

\begin{tabular}{|c|c|c|c|c|c|c|c|c|c|}
\hline \multirow{2}{*}{ Municipality } & \multirow{2}{*}{ Animals } & \multirow{2}{*}{$\mathbf{n}$} & \multicolumn{7}{|c|}{ Antibodies titers } \\
\hline & & & $1: 100$ & $1: 200$ & $1: 400$ & $1: 800$ & $1: 1,600$ & $1: 3,200$ & Total \\
\hline Santa Cruz do & Marsupials & 38 & 1 & 1 & 1 & 0 & 0 & 0 & 3 \\
\hline \multirow[t]{3}{*}{ Escalvado } & Rodents & 64 & 1 & 0 & 1 & 0 & 0 & 0 & 2 \\
\hline & Dogs & 119 & 0 & 0 & 4 & 3 & 0 & 1 & 8 \\
\hline & Horses & 111 & 0 & 0 & 3 & 3 & 2 & 1 & 9 \\
\hline \multirow[t]{5}{*}{ Pingo D’Água } & Marsupials & 01 & 0 & 0 & 0 & 0 & 0 & 0 & 0 \\
\hline & Rodents & 43 & 1 & 0 & 0 & 0 & 0 & 0 & 1 \\
\hline & Dogs & 25 & 1 & 0 & 0 & 0 & 0 & 0 & 1 \\
\hline & Horses & 44 & 0 & 0 & 4 & 2 & 0 & 0 & 6 \\
\hline & Total & 445 & 04 & 01 & 13 & 08 & 02 & 02 & 30 \\
\hline
\end{tabular}

Note: Serology against Borrelia using Borrelia burgdorferi of North American origin strain G39/40 performed by ELISA. $\mathrm{n}$ - number.

Table 3. Serological response against Leptospira spp. and Borrelia burgdorferi in wild and domestic animals $(n=445)$ from the municipalities of Santa Cruz do Escalvado and Pingo D'Água, Minas Gerais State, Brazil.

\begin{tabular}{lcc}
\hline \multirow{2}{*}{\multicolumn{1}{c}{ Organism }} & \multicolumn{2}{c}{$\begin{array}{c}c \\
\text { nrequencies of antibodies }\end{array}$} \\
\cline { 2 - 3 } & Positive & Negative \\
\hline Borrelia burgdorferi (only) & $10(2.25)$ & $435(97.75)$ \\
Leptospira spp. (only) & $211(47.42)$ & $234(53.58)$ \\
Borrelia burgdorferi + Leptospira spp. & $20(4.49)$ & $425(95.51)$ \\
\hline
\end{tabular}

Note: Serology against Leptospira spp. (30 serovars) performed by microscopic agglutination test; Serology against Borrelia using Borrelia burgdorferi of North American origin strain G39/40 performed by ELISA. $\mathrm{n}$ - number; $\%$ - percentage.

Amblyomma spp. ( $\mathrm{n}=74)$, Rhipicephalus (Boophilus) microplus $(\mathrm{n}=198)$, Rhipicephalus sanguineus $(\mathrm{n}=659)$, and Dermacentor nitens $(\mathrm{n}=133)$. The following flea species were also identified: Ctenocephalides canis $(n=691)$, Ctenocephalides felis $(n=80)$, Xenopsylla cheopis $(\mathrm{n}=19)$, Pulex irritans $(\mathrm{n}=1)$, and Rhopalopsyllus sp. $(\mathrm{n}=38)$.

The 3,821 ectoparasites collected were organized into 1,395 pools to DNA extraction, according host and evolutionary stage. The molecular analysis using the primers $\lg E 470 \mathrm{FW}$ (5'-CGCCTATTCTAACTTGACCCGAAT-3') and $f g E 470 \mathrm{Rev}$ (5'-TTAGTGTTCTTGAGCTTAGAGTTG-3') was performed as previously described (SAL et al., 2008; BILLINGS et al., 1998; MANTOVANI, 2010). Nested-PCR assays presented negative results for the 3,821 DNA samples tested.

The results of our work support the evidence of Borrelia spp. infection in wild and domestic animals; it was lowest in rodents (2.80\%) and highest in horses (9.68\%). In the municipality of Santa Cruz do Escalvado the highest antibody titers were found, especially in serum samples collected from dogs and rodents. Similar results were observed by Alves et al. (2004) in dogs from the metropolitan region of Rio de Janeiro, Brazil, with titles ranging from 1:400 to 1:6,000.

Serological evidence of $B$. burgdorferi infection in dogs was observed in $6.25 \%$ animals; this frequency was similar to date previously reported in areas of risks to Lyme disease. In a study with 237 dogs from the risk area of Cotia, State of São Paulo, Joppert (1995) demonstrated by ELISA 33 animals (9.70\%) showing IgG antibodies against B. burgdorferi.

In horses tested, $9.68 \%$ presented antibodies against $B$. burgdorferi, indicating the potential relevance of horses in the epidemiology of Borrelia spp. or non-identified BYS agent transmission. This result is similar to the results found in the municipalities of Três Rios and Vassouras in the State of Rio de Janeiro, Brazil (MADUREIRA et al., 2007).

In relation to wild animals, three of the 39 samples examined of marsupials (7.69\%). showed antibodies against B. burgdorferi.

Barros-Battesti (1998) captured 62 marsupials and 72 rodents in a residential condominium located in the Atlantic Rain forest in the municipality of Itapevi, State of São Paulo, where the first cases of BYS in brothers were described in Brazil. This author observed under dark field microscopy the presence of Borrelialike spirochetes in blood of $13.00 \%$ marsupials and $36.40 \%$ wild rodents. Despite of low frequency of antibodies against $B$. burgdorferi verified in rodents $(2.80 \%)$, these animals are considered major reservoirs and carriers of some Borrelia species (PAVLOVSKY, 1965; BARBOUR; HAYES, 1986).

By nested-PCR, using $f g E$ primers, the DNA samples from 3,821 ticks collected in three municipalities showed negative results. Similar results were obtained by Ataliba (2006), who used nested-PCR to verify the presence of Borrelia DNA in a total of 349 A. cajennense adult ticks collected from BYS suspected areas. We propose some explanations to justify these PCR negative results: (1) The etiological agent of BYS is quite different from the $B$. burgdorferi described in LD, since it is probably found at its atypical morphology cystic presentation (MANTOVANI et al., 2007, 2012; MANTOVANI, 2010); (2) The BYS is caused by a new Borrelia species, or by a genetically modified B. burgdorferi strain, or other spirochete that was not yet described, that do not can be correctly identified when using B. burgdorferi Northern hemisphere primers (MANTOVANI et al., 2007, 2012; YOSHINARI et al., 2010); (3) As a rule, enormous amounts of DNA are necessary to obtain positive nested-PCR with the use of $f g E$ primer in Brazil (MANTOVANI, 2010; MANTOVANI et al., 2012).

In conclusion, although the obtained results require further studies aiming the characterization of the etiologic agent in both samples of wild and domestic animals, the research demonstrated 
by the first time in the State of Minas Gerais, Brazil, serological evidence of circulation of borrelia or the other related agent in wild and domestic animals in the municipalities of Santa Cruz do Escalvado and Pingo D'Água. Further research is required to provide information on the presence of Borrelia in Brazilian territory and its association with Baggio-Yoshinari syndrome.

\section{References}

Alves AL, Madureira RC, Silva RA, Corrêa FN, Botteon RCCM. Frequência de anticorpos contra Borrelia burgdorferi em cães na região metropolitana do Rio de Janeiro. Pesq Vet Bras 2004; 24(4): 203-6. http:// dx.doi.org/10.1590/S0100-736X2004000400006

Aragão H, Fonseca F. Notas de ixodologia. VIII. Lista e chave para os representantes da fauna ixodológica brasileira: notas de ixolodologia. Mem Inst Oswaldo Cruz 1961; 59(2): 115-29. PMid:13861962. http:// dx.doi.org/10.1590/S0074-02761961000200001

Ataliba AC. Estudo de Borrelia spp. no Brasil [Dissertação]. São Paulo: Universidade de São Paulo; 2006.

Barbour AG, Hayes SF. Biology of Borrelia species. Microbiol Rev 1986; 50(4): 381-400. PMid:3540570 PMCid:PMC373079.

Barros-Battesti D. Estudos de carrapatos e pequenos mamiferos silvestres naturalmente infectados com espiroquetas semelhantes à Borrelia, no município de Itapevi, Estado de São Paulo [Tese]. São Paulo: Universidade de São Paulo; 1998. PMid:9921290.

Billings AN, Yu XJ, Teel PD, Walker DH. Detection of a spotted fever group Rickettsia in Amblyomma cajennense (Acari: Ixodidae) in South Texas. J Med Entomol 1998; 35(4): 474-8. PMid:9701930.

Costa IP. Pesquisa de anticorpos anti-Borrelia e do agente etiológico, em soro e líquor de pacientes com manifestaçóes clínicas compativeis com a Doença de Lyme, no Estado de Mato Grosso do Sul [Tese]. São Paulo: Universidade de São Paulo; 1998.

Gouveia EA, Alves MF, Mantovani E, Oyafuso LK, Bonoldi VL, Yoshinari NH. Profile of patients with Baggio-Yoshinari Syndrome admitted at "Instituto de Infectologia Emilio Ribas". Rev Inst Med Trop São Paulo 2010; 52(6): 297-303. PMid:21225212.

Grodzicki RL, Steere AC. Comparison of Immunoblotting and Indirect enzyme-linked immunosorbent assay using different antigen preparations for diagnosing early Lyme disease. J Infect Dis 1988; 157(4): 790-7. http://dx.doi.org/10.1093/infdis/157.4.790

Joppert AM. Estudo soro-epidemiológico da infecção por Borrelia burgdorferi em cães da região de Cotia, São Paulo [Dissertação]. São Paulo: Universidade de São Paulo; 1995.

Krupka M, Raska M, Belakova J, Horynova M, Novotny R, Weigl E. Biological aspects of Lyme disease spirochetes: Unique bacteria of the Borrelia burgdorferi species group. Biomed Pap Med Fac Univ Palacky
Olomouc Czech Repub 2007; 151(2): 175-86. PMid:18345249. http:// dx.doi.org/10.5507/bp.2007.032

Linardi PM, Guimarães LR. Sifonápteros do Brasil. São Paulo: FAPESP; 2000. 291 p.

Madureira RC, Corrêa FN, Cunha NC, Guedes DS Jr, Fonseca AH. Ocorrência de anticorpos homólogos anti-Borrelia burgdorferi em equinos de propriedades dos municípios de Três Rios e Vassouras, estado do Rio de Janeiro. R Bras Ci Vet 2007; 14(1): 43-6.

Mantovani E, Costa IP, Gauditano G, Bonoldi VLN, Higuchi ML, Yoshinari, NH. Description of Lyme disease-like syndrome in Brazil. Is it a new tick borne disease or Lyme disease variation? Braz J Med Biol Res 2007; 40(4): 443-56. PMid:17401487. http://dx.doi.org/10.1590/ S0100-879X2006005000082

Mantovani E, Marangoni RG, Gauditano G, Bonoldi VLN, Yoshinari NH. Amplification of the flgE gene provides evidence for the existence of a Brazilian borreliosis. Rev Inst Med Trop São Paulo 2012; 54(3): 153-7. PMid:22634887. http://dx.doi.org/10.1590/ S0036-46652012000300007

Mantovani E. Identificação do agente etiológico da doença de Lyme símile brasileira (Sindrome de Baggio-Yoshinari) [Tese]. São Paulo: Universidade de São Paulo; 2010.

Oliveira JA, Bonvicino CR. Ordem Rodentia. In: Reis NR, Peracchi AL, Pedro WA, Lima IP. Mamíferos do Brasil. Londrina: Imprensa da UEL; 2006. p. 347-406.

Pavlovsky EN. Natural nidality of transmissible diseases in relation to landscape epidemiology of zooanthroponoses. Moscow: Peace Publishers; 1965. 248 p.

Postic D, Merien F, Perolat P, Baranton G. Diagnostic biologique Leptospirose-Borreliose de lyme. Paris: Institut Pasteur; 2000. 248 p.

Ranka R, Bormane A, Salmina K, Baumanis V. Identification of three clinically relevant Borrelia burgdorferi sensu lato genospecies by PCR-Restriction fragment length polymorphism analysis of 16S-23S ribosomal DNA spacer amplicons. J Clin Microbiol 2004; 42(4): 1444-9. PMid:15070987 PMCid:PMC387532. http://dx.doi.org/10.1128/ JCM.42.4.1444-1449.2004

Rossi R, Bianconi G, Pedro WA. Ordem Didelphimorphia. In: Reis NR, Peracchi AL, Pedro WA, Lima IP. Mamiferos do Brasil. Londrina: Imprensa da UEL; 2006. p. 27-76.

Sal MS, Li C, Motalab MA, Shibata S, Aizawa SI, Charon NW. Borrelia burgdorferi uniquely regulates its motility genes and has an intricate flagellar hook basal body structure. J Bacteriol 2008; 190(6): 1912-21. PMid:18192386 PMCid:PMC2258876. http://dx.doi.org/10.1128/ JB.01421-07

Yoshinari NH, Mantovani E, Bonoldi VLN, Marangoni RG, Gauditano G. Doença de lyme-símile ou Síndrome Baggio-Yoshinari: zoonose exótica e emergente transmitida por carrapatos. Rev Assoc Med Bras 2010; 56(3): 363-9. PMid:20676548. http://dx.doi.org/10.1590/ S0104-42302010000300025 